\title{
Ian Bullock, Romancing the Revolution: The Myth of Soviet Democracy and the British Left (Edmonton: Athabasca University Press, 2011).
}

Bullock examines the responses to the revolution in Russia in the pages of the newspapers of the Independent Labour Party (ILP), the shop steward's movement, the Socialist Labour Party (SLP), British Socialist Party (BSP), National Guilds League (NGL), Workers' Socialist Federation (WSF), and National Socialist Party (NSP). He lavishes about 160,000 words on his theme, though most of what he has to say covers a period of only four or five years. The largest of these groups by far was the ILP with around 30,000 members in 1918, while the smallest such as the WSF were measured in hundreds (the SLP claimed just 1,258 in 1920, falling to 100 in 1924).

All these groups advocated various measures of direct democracy, though the ILP, the largest of them, was committed to British parliamentary democracy in ways that the others rejected. Revolution in Russia excited them all from the moment the Tsar fell. Undoubtedly it was the prospect of escaping the stalemate of the war and establishing a new internationalism that could prevent future wars, which most aroused this enthusiasm, especially when Kerensky declared his war aims, on 24 May, involving a peace without indemnities and annexations. The Leeds Convention hastily convened for 3 June testified to that enthusiasm and its causes. Two thousand people attended and all but a handful, according to Bertrand Russell, voted in favour of its four resolutions, the last of which called for the establishment of soviets in Britain. (R. Monk, Bertrand Russell: The Spirit of Solitude (London: Vintage, 1997), 407-8.) Russell, like many of the others attending this event, had opposed the war since it began.

The British left had very little idea of what the Soviets were in June 1917. In October, when a Bolshevik government was formed, few had heard of the Bolsheviks - something they had in common with most Russians at the start of that year. Yet the far left was quick to conclude that the Bolsheviks enjoyed majority support. When the Bolsheviks dissolved the Constituent Assembly in January 1918, most of the far left groups accepted the argument that soviet democracy was superior to bourgeois democracy and had made the Constituent Assembly redundant, if not actually reactionary. The one dissenting far left voice was that of the NSP, composed of the pro-war Hyndmanites, who opposed the Bolshevik 'tyranny' from its first year of existence. Justice ran articles exposing the lawless violence of the Bolsheviks and the NSP organised meetings with an anti-Bolshevik thrust. But far from seeing a tyranny the other groups stressed the direct nature of soviet democracy, its responsiveness to the people's will, its capacity for popular management of the economy, its association with workers' 
control of industry, and its exclusion of parasites and reactionaries. Positive appraisals of the soviets also appeared in journals such as the New Statesman and the ILP's Labour Leader in 1919 and 1920 but these journals also found space for articles which condemned the Bolsheviks disregard for democracy. The British Left was fearful of anything that might encourage Lloyd George to intervene militarily against the Bolsheviks in 1920, as the Russo-Poland war raged. The ILP was also divided over the question of whether it should join the Communist International until 1921. Such considerations influenced their judgments. But sympathetic observers such as Bertrand Russell, Arthur Ransome, and the British Labour Party delegation to Russia were all quite clear by 1920 that a Bolshevik dictatorship had been established, not a workers' dictatorship and certainly not government by direct democracy. In the event, only around 500 members of the ILP resigned to join the Communist Party when the ILP finally rejected affiliation to the Comintern in 1921.

By this time the SLP had also rejected Bolshevism and returned to an emphasis on its original De Leonist approach. Silvia Pankhurst's Dreadnought reflected much that was Communist orthodoxy and yet insisted on freedom of speech - for example to criticise the Comintern's misunderstandings about British politics and to support the anti-parliamentary Communists denounced in Lenin's Left-Wing Communism; An Infantile Disorder. Pankhurst was soon expelled from the Communist Party and by 1922 articles in Dreadnought were clear that the Bolsheviks had established a repressive dictatorship. Meanwhile those who gravitated to the Communist Party passed through council democracy and the necessity of the dictatorship of the proletariat to the realisation that the Leninist vanguard party was what really mattered for those interested in promoting socialism. Soviets were an expression of revolutionary crisis and a device for seizing power. Lenin, Trotsky, and the Comintern were of course the prime movers in effecting this ideological shift without, however, ever dumping the argument that soviets represented a higher form of democracy in both theory and practice.

Walter Kendall bemoaned this Bolshevik seduction of the British farleft, a left he described as hitherto 'ultra-democratic' and 'opposed to leadership on principle' in his Revolutionary Movement in Britain (1969). Gone were a variety of ideological alternatives, as one by one the newspapers and organisations of the old far left shut down and the CP took monopoly control of Marxism. Bullock is convinced that the myth of Soviet democracy played a crucial role in this seduction and transformation. He thinks one only has to consider what the effect on the British left would have been if the Bolsheviks had seized power without claiming to be champions of the soviets. But let us think about that. The Bolsheviks would still have claimed credit for taking Russia out of the war and breaking up parts of the Tsarist Empire. They would have exposed the 
secret treaties anyway and enhanced their anti-imperialist credentials further with the independence of Finland, the Baltic states and Ukraine under the terms of the Treaty of Brest-Litovsk. The war of intervention, the cordon sanitaire, the backwardness of Russia and the civil war would have supplied lots of reasons for giving them the benefit of the doubt when they retreated from the revolutionary principles they announced in October 1917. More importantly, perhaps, the Bolsheviks actually had power, and kept it in the name of socialism. For two decades to come there was little to show for socialism anywhere else. Lenin's idea that 1914 had opened up an epoch of wars, civil wars, revolutions and the decline of bourgeois democracy was supported by plenty of empirical evidence in the inter-war years. The vanguard party had much to recommend it in these circumstances and compared favourably to the experience of social democracy and the pre-Bolshevik amateurism of the Marxist left in its ability to organise and focus popular discontents. Finally the temper of the far left in 1918 is not captured merely by its talk of direct democracy so much as its conviction that parliamentary government best represented the enemy. The enemy had just presided over the greatest man-made catastrophe to date. It was tempting to think that the Bolsheviks had found a way to dispose of it and that socialists who really meant business would have to do as they had done.

John Callaghan

University of Salford

\section{Alvin Finkel, Sarah Carter, and Peter Fortna, The West and Beyond: New Perspectives on an Imagined Region (Edmonton: Athabasca University Press, 2010).}

The West and Beyond: New Perspectives on an Imagined Region has a history of its own. Published by Athabasca University Press and edited by Alvin Finkel, Sarah Carter, and Peter Fortna, the collection of essays springs from the like-named The West and Beyond: Historians Past, Present and Future conference, held at the University of Alberta in 2008. The conference envisioned itself as heir to the annual Western Canadian Studies Conferences of old, which had begun in the late 1960s and continued into the early 1990s (xi-xv). Throughout that series, politicians, western proponents, and academics rubbed shoulders in equal measure making the conferences as much about protecting or promoting the west as they were about studying it. Today's project is interested in moving beyond Western alienation; a confining narrative under which "the West" became a battle ground for regional elites rather than a space for lived experience. The West and Beyond is far more interested in imagining a region, than in defending it. 